\title{
IoT and Raspberry Pi application in the food industry: a systematic review
}

\author{
Aplicação de IoT e Raspberry Pi na indústria de alimentos: uma revisão sistemática \\ Aplicación de IoT y Raspberry Pi en la industria alimentaria: una revisión sistemática
}

Received: 12/02/2021 | Reviewed: 12/07/2021 | Accept: 12/15/2021| Published: 01/01/2022

Creciana Maria Endres

ORCID https://orcid.org/0000-0002-5662-2197 SENAI Chapecó College of Technology, Brazil E-mail: creciana.endres@edu.sc.senai.br

Crivian Pelisser

ORCID: https://orcid.org/0000-0001-7625-2755 SENAI Chapecó College of Technology, Brazil E-mail: crivian.pelisser@edu.sc.senai.br

Doglas André Finco

ORCID: https://orcid.org/0000-0002-3505-8996 SENAI Chapecó College of Technology, Brazil E-mail: doglas.finco@edu.sc.senai.br

Maristela Schleicher Silveira

ORCID: https://orcid.org/0000-0002-0468-2411 SENAI Chapecó College of Technology, Brazil maristela.silveira@edu.sc.senai.br

Valério Junior Piana

ORCID: https://orcid.org/0000-0003-2579-2318 SENAI Chapecó College of Technology, Brazil valerio.piana@edu.sc.senai.br

\begin{abstract}
The Industry 4.0 technologies are in ascension in the worldwide market, in Brazil still needs to be explored. It was made a Systematic Review to measure the application of IoT in the food industry. Some platforms were used to select works, applying the string "IoT AND Raspberry Pi AND Cheese". It was possible to evidence the majority of IoT applications in the food industry, focus on the control of temperature, humidity, color, traceability of productive chain, and enlargement of sustainability in the food industry. The most difficulties faced in the conventional application of IoT are related to the high cost of proprietary arquitectures, qualified manpower and obstacles of data security implementation. There are alternatives that aim to reduce the costs of implementation, like the utilization of Raspberry Pi. The food industry presents potential application of technologies that aim for the quality of products, being an excellent opportunity.
\end{abstract}

Keywords: Industry 4.0; oT; Raspberry Pi.

\section{Resumo}

As tecnologias da Indústria 4.0 estão em ascensão no mercado mundial, no Brasil ainda precisa ser explorado. Foi feita uma Revisão Sistemática para medir a aplicação da IoT na indústria de alimentos. Algumas plataformas foram utilizadas para selecionar os trabalhos, aplicando-se a string "IoT AND Raspberry Pi AND Cheese". Foi possível evidenciar a maioria das aplicações da IoT na indústria de alimentos, com foco no controle de temperatura, umidade, cor, rastreabilidade da cadeia produtiva e ampliação da sustentabilidade na indústria de alimentos. As maiores dificuldades enfrentadas na aplicação convencional da IoT estão relacionadas ao alto custo das arquiteturas proprietárias, mão de obra qualificada e obstáculos na implementação da segurança de dados. Existem alternativas que visam reduzir os custos de implantação, como a utilização do Raspberry Pi. A indústria alimentar apresenta potencial de aplicação de tecnologias que visam a qualidade dos produtos, sendo uma excelente oportunidade.

Palavras-chave: Indústria 4.0; IoT; Raspberry Pi.

\section{Resumen}

Las tecnologías de Industria 4.0 están en ascenso en el mercado mundial, en Brasil aún hay que explorar. Se realizó una Revisión Sistemática para medir la aplicación de IoT en la industria alimentaria. Se utilizaron algunas plataformas para seleccionar obras, aplicando la cadena "IoT Y Raspberry Pi Y Queso". Se pudo evidenciar la mayoría de las aplicaciones de IoT en la industria alimentaria, enfocadas en el control de temperatura, humedad, color, trazabilidad de la cadena productiva y ampliación de la sostenibilidad en la industria alimentaria. Las mayores dificultades que enfrenta la aplicación convencional de IoT están relacionadas con el alto costo de las arquitecturas propietarias, la mano de obra calificada y los obstáculos de la implementación de la seguridad de datos. Existen alternativas que apuntan a reducir los costos de implementación, como la utilización de Raspberry Pi. La industria alimentaria 
presenta una potencial aplicación de tecnologías que apuntan a la calidad de los productos, siendo una excelente oportunidad.

Palabras clave: Industria 4.0; IoT; Raspberry Pi.

\section{Introduction}

The food industry is in constant evolution, because the worldwide demand for agricultural products is increasing every year. Due to the productive potential of the Brazilian agricultural sector, it is believed Brazil could help to fulfill this demand. Therefore, it is necessary investment and support for the agricultural science, innovation, infrastructure, and fortification of the educational institutions. Other tendency of the sector is the fortification of quality process, food safety, environmental sustainability, and human rights (Barros, 2020; Misiou \& Koutsoumanis, 2021).

In 2019, the Brazilian food industry presented an profit of 699.9 billion Brazilian Reais, being $6.7 \%$ larger than the year of 2018 (ABIA, 2020). This raise is incipient, whereas the majority of the companies of the food sector in Brazil and the world are dependent on basic systems of 2nd and 3rd industrial revolutions (Mattas \& Tsakiridou, 2010; Sakurai \& Zuchi, 2018). Hence, it is extremely necessary to explore and implant the technologies of 4th industrial revolution through the data collection, real-time monitoring, control, automation, prediction, traceability, additive manufacturing, and blockchain.

In the last 10 years the food industry has not presented a significant raise in terms of technology and innovation in comparison to other industrial sectors. According to Paladino et al. (2019), the sector of packaging is the most propitious to develop innovation. Hardly the productive area that involves control of process, sensing and digitalization presents news. For example in the dairy sector, the main wagon of Brazilian agribusiness, that holds few technologies and needs new researches that aims to facilitate the monitoring of food quality and production, like the application of industry 4.0 technologies.

Duong et al. (2020) have studied the application of robotics and autonomous systems in the food supply chain, food quality, food safety and food waste. Prasanth et al. (2020) developed an portatile spectrophotometer from an open source computer (Raspberry Pi) that brings low cost, components of open source code for the analysis of fat and water added in the milk, optimizing the time of analysis. Alfian et al. (2020) used RFID sensors (Radio-Frequency IDentification) to track perishable foods and IoT to control the temperature and humidity during the transportation, providing information in real time. Bouzembrak et al. (2019) in their work revision article verified that the most used communication technologies for monitoring the supply chain are by radiofrequency (RFID) and a wireless sensor network (RSSF). Vyas et al. (2019) used a microcontroller and an algorithm of machine learning (neural networks) for the detection of foot-and-mouth disease and mastitis in a dairy herd allowing an improvement in milk quality, as well as cost reduction of processing for the dairy.

A systematic review was carried out to observe the application of Industry 4.0 enabling technologies in the food industry. To find studies that have this approach used the keywords IoT AND Raspberry-Pi AND Cheese. We chose to use the term cheese instead of food to focus on the dairy industry, which has a greater deficiency in food technologies.

The 4th industrial revolution or Industry 4.0 supports itself in the integration of information and communication technologies, allowing the generation of new strategies and business models for the industry. The technologies which act as pillars for the modernization of the actual scenario are Big Data, Cloud Computing and IoT. Big Data refers to the enormous quantity of data generated in the industrial and commercial processes, and also related to the behavior of the user. For the ease of use, the generated data could be stored in servers of different regions through Cloud Computing. Another relevant aspect is that the objects start to have sensors and actuators, beyond the capability of connecting itself to the internet and interacting with humans or other objects, such technology is defined as IoT (Duong et al., 2020; Sacomano et al., 2018).

The IoT consists in an infrastructure of technology of information and communication for the gathering and distribution of data that could influence the efficiency and performance of the systems. With the use of IoT it is possible to connect heterogeneous devices, manage and exchange information, in addition to track the location with precision, 
optimization of energy consumption, preservation of privacy and security, allowing the use of technologies of wireless communication (Duong et al., 2020; lawal \& Rafsanjani, 2021).

Lawal \& Rafsanjani, (2021), basing on different architectures of IoT in the literature, shown a general architecture that the system is composed of four main layers: (1) Physical layer, (2) Cloud layer, (3) Communication layer and (4) Service layer. Those four layers cover hardware, software, network and aspects of integration needed for any approach of IoT (Figure $1)$.

Figure 1. General arquitecture of IoT.

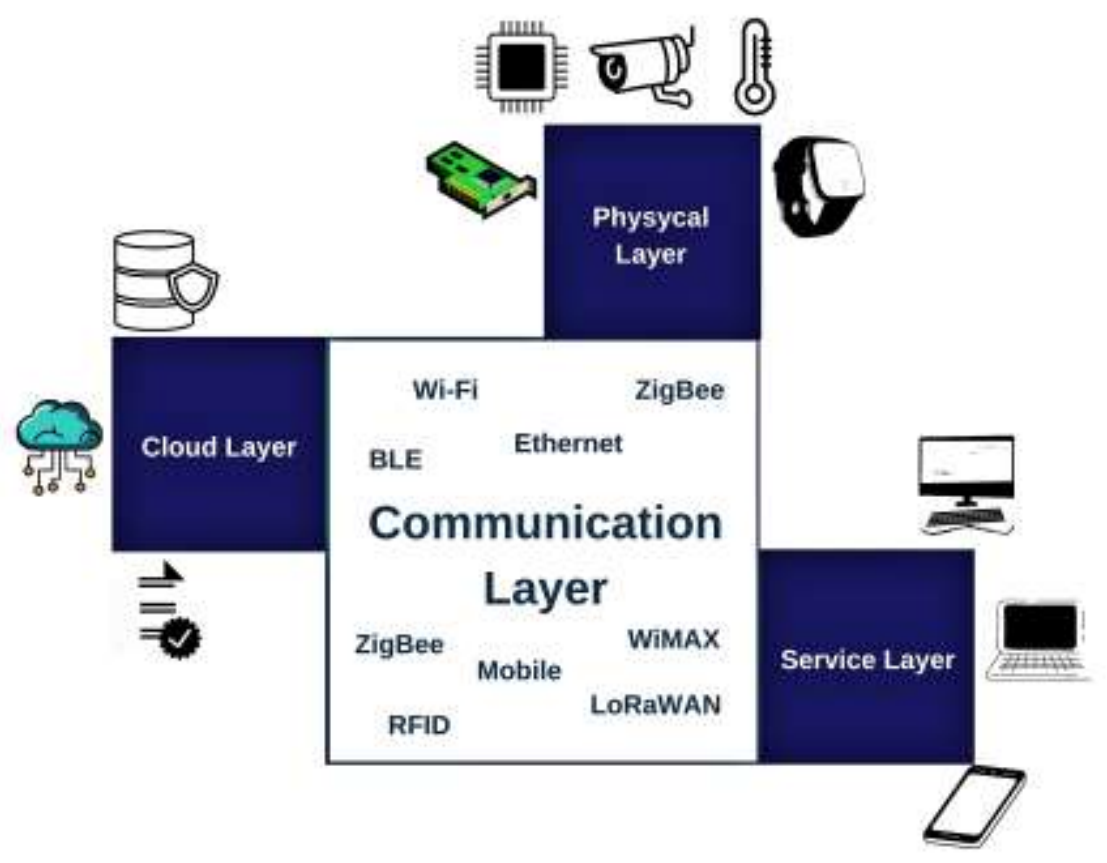

Source: Authors (2021).

The application of IoT technologies is already a reality in the automotive industry (Rahim et al., 2021), in the pharmaceutical industry (Safkhani et al., 2020) and in the manufacturing industries that include power source, water management, chemical products, and materials (Venkata Lakshmi et al., 2021). However, in the food industry the application of those habilitating technologies are still little significant (Duong et al., 2020).

Although these IoT approaches have been developed for some areas of the food sector, there is still need for improvements on the operation and application, in order to understand the potential of those technologies. In this way, this article presents a systematic review that tackles the following questions: (I) what are the main characteristics of the selected studies; (II) what are the used systems platforms; (III) what are the most used sensors; (IV) what are the earnings of the industry with the IoT application; (V) what are the limitations and challenges of industry. The study will provide data and insights that will contribute to the application of technologies in the food industry. 


\section{Methodology}

This article follows an method of systematic revision of literature descripted by Kitchenham \& Charters, (2007). The use of this methodology identifies gaps in the literature and provides trustworthy data for future researches. This research was realized in three stages - Planning (1), conduction (2) and presentation of revision (3).

\subsection{Identification of data}

The article provides a wide review of the current literature, beyond providing tendencies, challenges and limitations of researching that deserve to be investigated in the context of application of IoT in the food industry, in special dairy industry.

The collection of data was realized including sources of data and keywords, necessary to the systematic review. It has been formulated five research questions (RQs), to explore each aspect of those objectives in a suitable manner. The Board 1 presents a general revision of the RQs, like the motivation for the search of answers of each them.

Board 1. Description of research questions and main motivations.

\begin{tabular}{|c|c|c|}
\hline ID & Question & Main motive \\
\hline RQ01 & What are the main characteristics of the study? & Identify the characteristics and focus on each study. \\
\hline RQ02 & Which system platform was used in the study? & $\begin{array}{c}\text { Observe the technologies used in the construction of the } \\
\text { study. }\end{array}$ \\
\hline RQ03 & What sensors are used to collect data in the food industry? & $\begin{array}{c}\text { Know the types of sensors used for data collection in the } \\
\text { food industry. }\end{array}$ \\
\hline RQ04 & $\begin{array}{c}\text { What are the gains of the industry with the application of } \\
\text { the proposal of each study? }\end{array}$ & $\begin{array}{c}\text { Understand the main advantages for the industry in the } \\
\text { use of these technologies. }\end{array}$ \\
\hline RQ05 & $\begin{array}{c}\text { What are the industry's limitations and challenges in the } \\
\text { use of IoT? }\end{array}$ & $\begin{array}{c}\text { Understand the industry's limitations in deploying this } \\
\text { technology. }\end{array}$ \\
\hline
\end{tabular}

Source: Authors (2021).

The keywords defined from the evaluation of bibliographic review related to the application of low cost technologies in the food industry. The definition of the search string occurs based in the keywords indicated in the studied reviews, being "IoT AND Raspberry Pi AND Cheese".

\subsection{Research sources and selection strategy}

The articles were selected by automatic individual search. The libraries ACM and Science Direct were chosen because they are the main places of publication of articles related to the proposed theme. The Google Scholar was also used to search other studies in the area, because it explore other digital databases. All the researches were limited to articles that were published from 2016 to 2021, aiming to find current tendencies around the theme. The limit date of search was February, 16th, 2021. Due to this, only the published studies until this date are contemplated in the results.

\subsection{Process of selection, criteria for the inclusion and exclusion}

Initially it was developed an individual research using the string in each one of the digital databases. The process of searching identified 68 articles, that after the procedure of filtering, resulted in eleven different articles analysed. The adopted procedures excluded articles that did not have title, abstract or text adherent to the theme 
Because the data includes quantitative and qualitative answers, different approaches were used for the synthesis of the data. Descriptive synthesis was used for ease the visualization of the discoveries and also for the graphs and tables.

\section{Results}

There are in this section the results assembled by research question with basis in the extracted data in the primary studies.

\subsection{General aspects}

This section of descriptive analysis provides a general vision of the selected articles in this study. The Table 1 presents the quantity of the articles that has been found initially and also the quantity of articles selected after the application of the criteria or inclusion and exclusion.

Table 1. Quantitative of founded articles.

\begin{tabular}{ccc}
\hline Year & Articles Found & Selected Articles \\
\hline 2016 & 7 & 1 \\
2017 & 11 & 1 \\
2018 & 16 & 1 \\
2019 & 8 & 2 \\
2020 & 19 & 5 \\
2021 & 7 & 1 \\
\hline
\end{tabular}

Source: Authors (2021).

The Table 1 shows that has been a raise of the publications amount in 2019 and 2020, and in the year of 2021 the number of publications lowered because the sample was collected in February of 2021. The greatest number of studies was located in the Google Scholar, followed of the Science Direct and ACM.

The location from where the study was conducted is the most important factor, because through those informations is possible to map the countries that have been dedicating themselves to the researches in this theme (Figure 2). 
Figure 2. Place of realization of the selected studies.

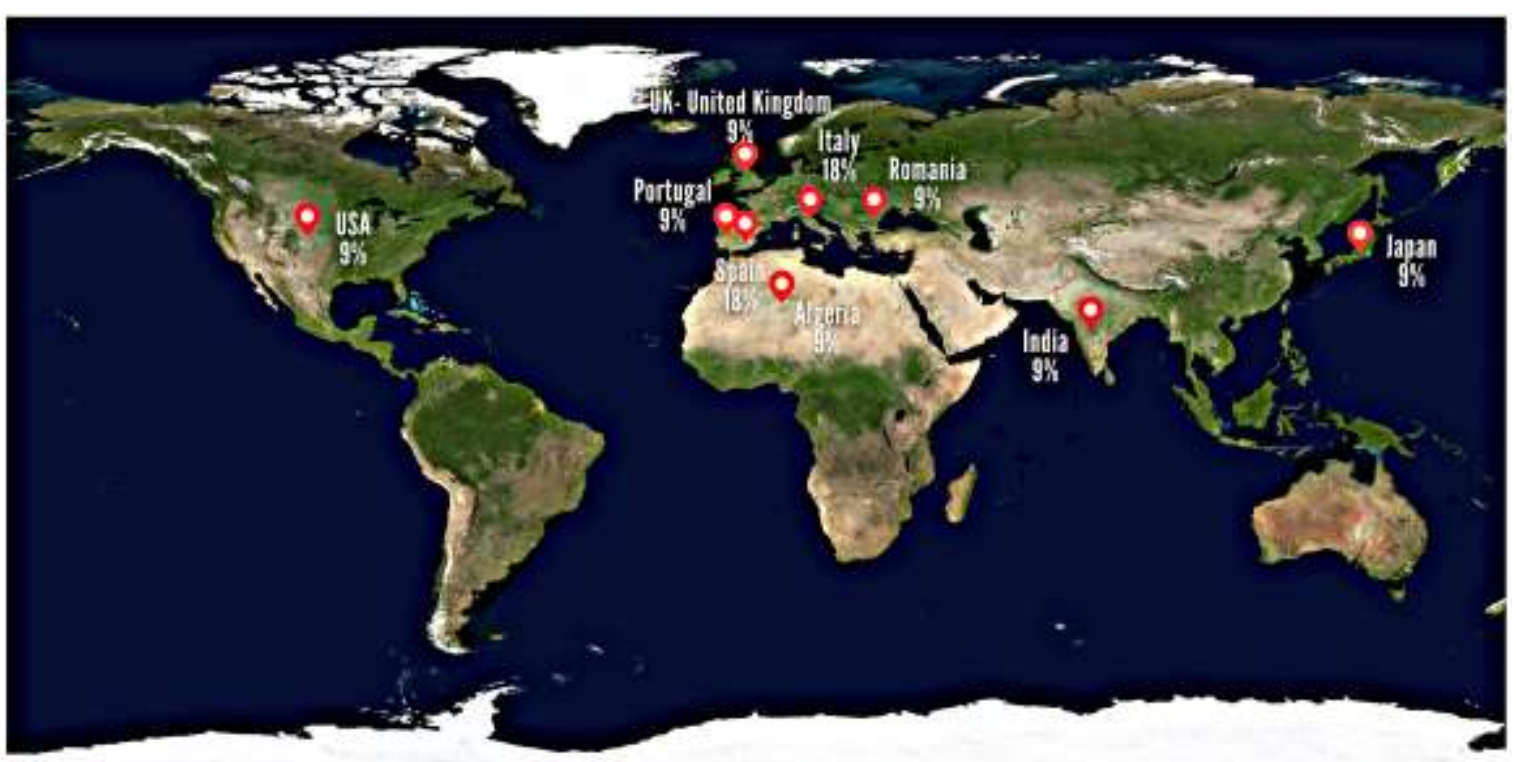

Source: Authors (2021).

According to the presentation, Spain and Italy, both located in Europe, were the countries where most studies were developed (18\%), meanwhile the others represented $9 \%$ of the publications. Furthermore, eight $(72,73 \%)$ were published in periodicals and three $(27,27 \%)$ were presented in conferences. Studies related to this area are commonly published in periodicals and conferences and are presented in distinct publication sources.

\subsection{Thematic Analysis}

This section presents the main characteristics of the studies related (RQ01), the platforms of utilized systems (RQ02), the main sensors applied in the food industry (RQ03), as well as the gains (RQ04) and the limitations of the industry in the application and utilization of technologies like IoT (RQ05).

\subsubsection{Application of technologies in the industry}

Jagtap et al. (2021) presented a structure based in IoT to monitor the generation of alimentary waste, the use of energy and water in the food sector in real time. The authors concluded that there is a big complexity associated to environmental sustainability, costs of food production, national and international compliance, besides consumer preferences and dietary requirements. The authors highlight that the food sector should adopt the concepts introduced in the 4th industrial revolution to optimize the efficiency of resources.

Alonso et al. (2020) used IoT, Edge Computing (EC) and Distributed Ledger Technologies (DLT) to create a platform that monitors in real time the state of the dairy cattle and of the grains for the ration, through the use of the environmental sensors of consumption of energy, animals body health, labels for the products, and transport conditions. Thus, guarantees the traceability and sustainability of the different processes involved in the production. The authors concluded that is possible to reduce the costs of transference of data between the IoT and the cloud, using the Global Edge Computing (GEC) Architecture.

Baralla et al., (2020) proposes the creation of a system with Blockchain to manage a food supply chain, thus can be tracked to verify conditions like storage temperature, environmental humidity and GPS data. This control is realized through a 
identification code(lot). The end consumer can verify the precedence, analysing the history of the product from the supply chain until the final revenue.

Herrero et al., (2020) used Raspberry Pi, a device of low cost, to measure some parameters of productivity in industrial environments and determine the disponibility of machines. The proposal improves the process efficiency providing data about availability and productivity of industrial machinery.

Jain et al., (2020) developed a sensor network system of low cost for monitoring quality tests of food dye. The proposed device consists in a combination of hardware and software (Color Magic), allowing that the hardware could be used both for quality testing and process monitoring applications. The results sugest that those devices are capable of detecting product color variation changing. The device could be applied in the assessment of quality and freshness of fruit and vegetables minimally processed.

Pal \& Kant (2020) approached a possibility of transforming the fresh food logistics in a smart cybernetic system, conducted by online monitoring and operational control associated to improve the freshness and the security of the food, reducing the waste and raising the transport and distribution efficiency.

Teixeira et al. (2020) implemented a maturation chamber used in traditional cheese fabrication. The chamber holds temperature control, humidity and gas composition, those parameters affect the microbial activity and product organoleptic characteristics. The authors concluded that the automation applied reduced the water consumption in $26 \%$ and the electric energy consumption in 9\%, causing great economic impact in small and medium companies, besides turning the process environmentally friendly.

Paladino et al. (2019) used a monitoring system type Supervisory Control and Data Acquisition (SCADA) of open source code and based in the web, developed ad-hoc to acquire, manage, aggregate, and show process data in real time in industries of small capital. Thereby, it is possible to control the fermentation process operation, dry out, filtering, separation, homogenization, ultra-high temperature (UHT), high temperature of short time (HTST), and all the main operations of units of first and second food processing plants.

Gupta \& Rakesh, (2018) propose a system of monitoring food adulterants, seeking store and marketplace installation for the utilization of customers in the detection of frauds or food contamination, like agrotoxic, lead among others. Thereunto, it would be necessary for example the use of temperature sensors, humidity, chlorides, $\mathrm{pH}$, and viscosity. Thus, raising the reliability in the marketed products.

Mededjel et al. (2017) proposed a system of food trackability based in IoT, cloud and hybrid cloud technologies, gathering information and registering events related to products in every place in the supply chain. The system accords to many requirements of trackability, like automatic identification, distributed/centered storage and data sharing, scalability support, heterogeneity, and answers in real time.

Floarea \& Sgârciu, (2016) presented the concept, the architecture, the construction process, and the functionality of a refrigerator using IoT. The stored items make transmissions to the platform that distributed the data to its owners.

\subsubsection{Systems platforms}

The system platforms unite the technologies approached in each study around the structure of hardware and software for the collection, transmission and data representation, according to Figure 3. 
Figure 3. Information and Communication Technologies used in the maped studies for the systematic review.

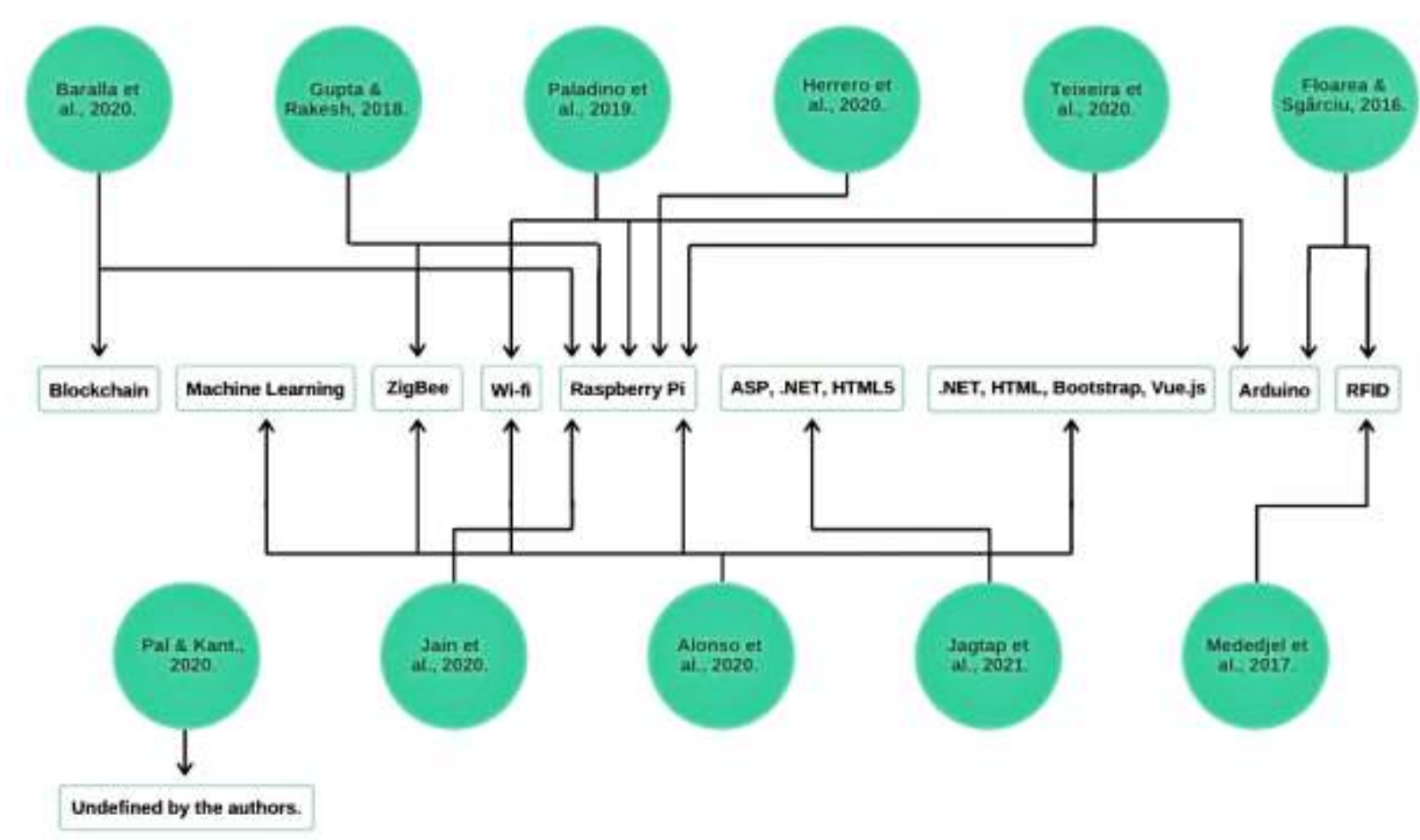

Source: Authors (2021).

According to Figura 3, the technology of greater application was Raspberry Pi, followed by Arduino, but other technologies both hardware and software are presented.

\subsubsection{Applied sensors}

During the application of new technologies, the data acquisition is extremely important, thereby many sensors were proposed in different studies, according to the Board 2. 
Board 2. Applied sensors in the selected studies for the realization of systematic review.

\begin{tabular}{|c|c|}
\hline Answer & Reference \\
\hline $\begin{array}{l}\text { The study used automated image sensors and weight control to monitor the amount of food waste generated. } \\
\text { In addition, it presents the use of sensors, to control energy and water consumption by means of pressure } \\
\text { transducers, flow meters and water quality sensors. }\end{array}$ & $\begin{array}{l}\text { (Jagtap et al. } \\
\text { 2021) }\end{array}$ \\
\hline $\begin{array}{l}\text { The authors present the use of environmental sensors to control temperature and relative humidity of the air, } \\
\text { sensors to measure gases such as methane, hydrogen sulfide, ammonia and formaldehyde, sensors for energy } \\
\text { consumption and solar production auditors. In addition, they present the use of agrometeorological stations in } \\
\text { plantations used to feed livestock (rain, temperature, relative humidity, anemometer, soil humidity and } \\
\text { temperature and solar radiation). In order to control the animals, real-time location sensors of vital levels were } \\
\text { used, including body temperature, breathing, heart rate and rumination. For the factories, RFID and QR Code } \\
\text { tags were used, which are used for the traceability of different packaged products (milk, cheese, butter, etc.), } \\
\text { as well as smart meters to monitor energy consumption. Finally, in terms of transportation, the conditions of } \\
\text { temperature, humidity and vibrations were monitored. }\end{array}$ & $\begin{array}{l}\text { (Alonso et al. } \\
2020 \text { ) }\end{array}$ \\
\hline In order to manage the food supply chain, temperature, humidity, and location sensors were applied. & $\begin{array}{l}\text { (Baralla et al. } \\
\text { 2020) }\end{array}$ \\
\hline $\begin{array}{l}\text { They did not present any sensor, because they are based on the energy consumption to perceive the } \\
\text { availability of the device. }\end{array}$ & $\begin{array}{l}\text { (Herrero et al. } \\
2020)\end{array}$ \\
\hline $\begin{array}{l}\text { The study presents the application of sensors for color reading, which allows monitoring and estimating the } \\
\text { quality of the product. }\end{array}$ & $\begin{array}{l}\text { (Jain et al. } \\
2020)\end{array}$ \\
\hline $\begin{array}{l}\text { The authors did not present the sensors used, since the study was not implemented. The focus was on } \\
\text { suggesting and exploring the topic. }\end{array}$ & $\begin{array}{l}\text { (Pal \& Kant, } \\
2020)\end{array}$ \\
\hline $\begin{array}{l}\text { Sensors for detecting the presence of cheese, inlet temperature and humidity, outlet air temperature and speed } \\
\text { were used in order to monitor the cheese ripening process. }\end{array}$ & $\begin{array}{l}\text { (Teixeira et } \\
\text { al. 2020) }\end{array}$ \\
\hline $\begin{array}{l}\text { The study used sensors of } \mathrm{pH} \text {, temperature, conductivity, pressure, humidity, dissolved oxygen and dissolved } \\
\text { carbon dioxide, all at low cost. }\end{array}$ & $\begin{array}{l}\text { (Paladino et } \\
\text { al. 2019) }\end{array}$ \\
\hline $\begin{array}{l}\text { Gupta \& Rakesh, (2018) applied sensors for temperature, oil, humidity, salt meter, } \mathrm{pH} \text {, color, viscosity and } \\
\text { electronic nose to control food quality. }\end{array}$ & $\begin{array}{l}\text { (Gupta \& } \\
\text { Rakesh, } \\
\text { 2018) }\end{array}$ \\
\hline $\begin{array}{l}\text { The study did not determine which sensors should be used in view of the fact that it is based on a proposal for } \\
\text { future application. }\end{array}$ & $\begin{array}{l}\text { (Mededjel et } \\
\text { al. 2017) }\end{array}$ \\
\hline $\begin{array}{l}\text { The Radio Frequency Identification (RFID) sensors were applied in the study to monitor the quantity of } \\
\text { products stored in a refrigerator. }\end{array}$ & $\begin{array}{l}\text { (Floarea } \\
\text { Sgârciu, } \\
\text { 2016) }\end{array}$ \\
\hline
\end{tabular}

Source: Authors (2021).

Several sensors are already used in the food industry, those provide data acquisition in real time, ease the trackability of the process and with this a quicker decision making.

\subsubsection{Industrial gains with the implementation of IoT}

The approaches in the papers have as goals the evolution of the current industry scenario. Towards this context, the Board 3 presents the main gains of the industry with the proposition of authors. 
Board 3. Gains to the industry after the application of different technologies.

\begin{tabular}{|l|l|}
\hline RQ06 - What are the industry gains with the application of the proposal of each study? & Reference \\
\hline $\begin{array}{l}\text { Decision making in the manufacture of food in a more strategic way, having a more efficient production. It } \\
\text { also contributes to the improvement of resources, which can be achieved by more efficient processing and } \\
\text { good manufacturing practices or by redesigning the manufacturing processes. }\end{array}$ & $\begin{array}{l}\text { (Jagtap et al., } \\
2021 \text { ) }\end{array}$ \\
\hline $\begin{array}{l}\text { Monitoring and traceability features and fast response time. } \\
\text { (Alonso et al., } \\
\text { process flow. }\end{array}$ & $\begin{array}{l}\text { (Baralla et al., } \\
\text { 2020) }\end{array}$ \\
\hline More effective control of the process from decision making based on the data collected. & (Herrero et al., \\
\hline $\begin{array}{l}\text { Mon) } \\
\text { Monitoring the quality of processes. }\end{array}$ & $\begin{array}{l}\text { (Jain et al., } \\
2020)\end{array}$ \\
\hline $\begin{array}{l}\text { Operational control for improvement in terms of freshness, safety, waste reduction, and improvement of the } \\
\text { logistics efficiency of food products on an online platform. }\end{array}$ & $\begin{array}{l}\text { (Pal \& Kant, } \\
\text { 2020) }\end{array}$ \\
\hline $\begin{array}{l}\text { Greater productive efficiency and reduced water and electricity consumption. } \\
\text { Optimization and analysis of process conditions, product quality through data post-processing, indicating } \\
\text { possible contamination, and tracking. }\end{array}$ & $\begin{array}{l}\text { (Teixeira et al., } \\
\text { 2020) }\end{array}$ \\
\hline $\begin{array}{l}\text { Application for personal or business purposes, allowing greater safety in food, so that consumption of poor } \\
\text { quality is avoided. }\end{array}$ & $\begin{array}{l}\text { (Gupta \& } \\
\text { Rakesh,, 2018) }\end{array}$ \\
\hline $\begin{array}{l}\text { Automatic identification, distributed/centralized storage and data sharing, with support for scalability, } \\
\text { heterogeneity and real-time responses. }\end{array}$ & $\begin{array}{l}\text { (Mededjel et } \\
\text { al., 2017) }\end{array}$ \\
\hline $\begin{array}{l}\text { Application of approaches that allow embedded devices to become more intelligent, reliable and autonomous. } \\
\text { (Floarea \& } \\
\text { Sgârciu, 2016) }\end{array}$ \\
\hline
\end{tabular}

Source: Authors (2021).

Among the gains, it is perceived a raise of monitoring resources and trackability of processes over the food chain in an efficient way, providing consequently better security and quality about all the productive sectors.

\subsubsection{Main limitations and challenges}

The adequation of industries in the use of IoT could face several challenges: the high cost, difficulties in implementation and security. The selected articles were analysed to verify the limitations that were found by the authors in the application of IoT in the industry, according to Board 4. 
Board 4. Limitations found for the application of IoT technologies in the industry.

\begin{tabular}{|l|c|c|c|c|c|c|}
\hline \multicolumn{1}{|c|}{ Selected Articles } & \multicolumn{5}{|c|}{ Limitations } \\
\cline { 2 - 7 } & Cost & System implementation & Lack of Technology & Data security & Packing & Others \\
\hline Jagtap et al. 2021 & $\mathrm{X}$ & & $\mathrm{X}$ & $\mathrm{X}$ & & \\
\hline Alonso et al. 2020 & $\mathrm{X}$ & $\mathrm{X}$ & $\mathrm{X}$ & & & \\
\hline Baralla et al., 2020 & $\mathrm{X}$ & $\mathrm{X}$ & & & & \\
\hline Herrero et al. 2020 & & & & & & $\mathrm{X}$ \\
\hline Jain et al. 2020 & $\mathrm{X}$ & & & & \\
\hline Pal \& Kant, 2020 & & & & & $\mathrm{X}$ & \\
\hline Teixeira et al. 2020 & & & & & & \\
\hline Paladino et al. 2019 & $\mathrm{X}$ & & & & & \\
\hline Gupta \& Rakesh, 2018 & $\mathrm{X}$ & & & & & \\
\hline Mededjel et al., 2017 & & & $\mathrm{X}$ & & \\
\hline Floarea \& Sgârciu, 2016 & & & & & \\
\hline
\end{tabular}

Source: Authors (2021).

Jagtap et al. (2021) enfathyse about the need of disruptive innovations in the sector, allowing the development of food factories bases in IoT edge to edge. Furthermore, there are problems associated with costs of installation, availability, usability, data security and national and international compliance. On the other hand Alonso et al. (2020) highlight that the main challenges founded was the high values of investment and also the technological availability, as well as the way of utilization which requires previous knowledge for handling the set (Hardware and Software), besides the difficulty for finding companies that render this type of service.

Teixeira et al. (2020) aim that the study was conducted in a low sampling, being necessary a high scale application for the comprovation of its viability, in addition to assess the impact in the physicochemical, microbiological and sensorial sheep cheese properties matured in the prototipe. Other point indicated as a challenge by the author is to compare this study with the chambers of default maturation, to homogeneous the environmental condition and of business competitive. Meanwhile, Jain et al. (2020) signal the challenge of monetary cost of applied sensors in complex processes, like platforms that use computational vision with application in the industry.

Baralla et al. (2020) comment about the limitations of implementation of a IoT system and Blockchain in the production and distribution chain, that needs the transformation of the equipments, engineering practices and retrofitting. Moreover, for the use of this technology there is a high energy consumption that raises with the measure which the network expands itself.

Herrero et al. (2020) highlight the electromagnetic interference (EMI) that the devices of low cost are subjected to in industrial scenarios. On the other hand, Pal \& Kant, (2020) problematize the need for technological and futuristic packaging of low cost with sensors to communicate information of food security directly to a centered repository. 
Paladino et al., (2019), claim that the high cost of sensors, hardware, software, managing, and storage of data hamper the application in small and medium companies, make the factor of innovation decrease. Besides that, there are weaknesses that are related to operations in high-risk plants and their emergency operation (immediately shut-down), in plants of high pressure in transient regime can be in danger, although this does not allow certification for being an open hardware/software.

The authors Gupta \& Rakesh, (2018) highlight the need for a continuous improvement that may turn the system more accessible in matter of costs and usability (human-computer interaction), besides suggesting the charges in a more effective way in the organizations about the Alimentary Security Compliance. The challenge is to allow the implementation in large scale of devices to monitor the food, reduce frauds and use of pesticides in a way of approaching the business to the customer.

Mededjel et al. (2017) sign that heterogeneity of the technologies, with frequency, limits the tasks that are mandatory for the connection and functionality in the tracking chain. Floarea \& Sgârciu, (2016) focus on the necessity of using a smart RFID package for the operation of its system control and, to find technological alternatives that allow the propagation of the waves within liquids or metals.

\section{Discussion and Analysis of the Results}

The majority of the selected articles was published in 2020, showing this theme is beginning to be explored. None of the selected studies was conducted in Brazil, it justifies the relevancy of the theme, beyond serving as motivation for the realization and implementation of the technologies in the food industries located in the country. Despite the present distinct properties, all of the studies seek the monitoring of the food productive chain, with focus on the process control and consequently the quality warranty of the final product.

The authors propose that one of the most important applications of the technologies belonging to industry 4.0, is the traceability. It is perceived that even applying systems of traceability for animals and animal feed (Alonso et al., 2020) or accompaniment of the companies and security of the products, or real accompaniment of the food productive chain (Baralla et al., 2020; Mededjel et al., 2017; Pal \& Kant, 2020) all present a focus that is the monitoring in real-time of the products. This eases the accompaniment of the companies and security of products, as well as speed and agility in the process of recall that could happen. Moreover, the studies characterize themselves in the guarantee of sustainability like reduction and energy/water control (Herrero et al., 2020; Jagtap et al., 2021), or reduction of food waste. This accompaniment is possible due to the utilization of IoT technologies.

When applying IoT the authors sought the data collection in real time, storing and creation of logs that allowed the sought accompaniment and assessment in different processes presented in selected articles. Other than that, when associng the Blockchain, according to the suggested by Baralla et al. (2020), enabled the security of the generated data, harding the access by external people. Thereunto, several communication and information technologies are approached, like the Raspberry Pi, followed by Arduino. The high incidence of Raspberry Pi was expected, because its contemplated in the search string and presents low cost, which eases its utilization. One of limiting factors for the definition of the platforms is the financial value of the investment intent, as well as required features.

Based on it, there are also the chosen sensors for utilization. Nowadays in the market are several options allowing the industrial sensoring along the productive chain, from simpler sensors to more sophisticated ones, that can be adapted to each reality. Jain et al. 2020 present in their study the application of color sensors, whose main function is determining the quality of food through this data, a factor that will significantly influence the food productive chain, reducing waste and contributing to the health of customers. Approximately half of the studies presented the use of temperature and humidity. Thereby, it is perceived those parameters as the greatest interest of the food industries. 
It is believed this interest is related to the conservation of the products, like shelf life, that is influenced directly by the variation of temperature and humidity. Besides the conservation of products, the industries were worried about the reduction of energy, water and food waste. Sensors that reduce or avoid those problems were proposed for several authors (Alonso et al., 2020; Herrero et al., 2020; Jagtap et al., 2021). Another important matter is the use of sensors to avoid food adulteration as presented by Gupta \& Rakesh, (2018). This study suggested the control of salt, pH, color, viscosity, and smell by means of an electronic nose. This accompaniment provides greater food security, avoiding the consumption of bad quality food. The authors suggested that with the application of those technologies, the gains will be noticed by the industries mainly in the productivity.

Alonso et al., (2020) and Mededjel et al., (2017) indicate that with the use of those technologies of industry 4.0, the companies will be able to act in a quick and efficient way in the problem resolution and with negotiations of act plans, in addition to promove the traceability of the process. Other observation pointed in the studies was the financial gains, occurred due to the reduction of water and energy consumption, influenced by the productive efficiency (Teixeira et al. 2020), food security, monitoring the whole process (Gupta \& Rakesh, 2018; Jagtap et al., 2021; Jain et al., 2020; Paladino et al., 2019) and transparency in the alimentary chain (Baralla et al., 2020; Pal \& Kant, 2020). It has been noticed the application of those approached technologies presented the viability of application in the food industry, however there are some limitations, such as high cost of development, implementation and hardness in finding companies which provide services to the industries. Besides, there is a difficulty to receive the certification of the competent organizations, security and reliability of data generated.

Those limitations justify the lower number of studies found in the literature by using the string "IoT AND RaspberryPi AND Cheese". The reduced number of researches complicates the application in the industry and itself approval of those technologies though the regulatory organizations, because those bases themselves in results of researches and data generated by industries to approve the use of new technologies.

With it in mind, it is necessary to observe the pointed challenges for the authors that will guide the future of the studies and application of new technologies in the food industry. The applicability of the studies in the field for the data gathering is extremely important, but it presents several challenges like the implementation in large scale, validation and acceptance of the regulatory organizations with sample and repeatability, operation of high risk plans, as well as accessible technologies; it demonstrated that new studies must be conducted to assess new technologies and costs for the implementation.

\section{Final Considerations}

Through application of the systematic review in the platforms of Google Scholar, Science Direct and ACM, it was possible to select 11 articles related to the search string "IoT AND Raspberry-Pi AND Cheese". It highlights that approximately 55\% of the articles were published in the years of 2020 and 2021 (by February) andshows the relevancy of the theme. It is noticed it is a big necessity for research in this area, whereas Brazil is among the greatest food producers of the world and none of the selected studies were conducted in this country.

Regarding the selected articles, there are many applications in the food industry: temperature and humidity control relevant due the high perishability of finished product; food color control - it aids in verification of quality, reducing the waste and avoiding the consumption of foods of bad quality; application in traceability of productive chain - impacts directly in the quality of food, mitigating the number of frauds and easing the procedures of recall.

Besides that, the technology of IoT was widely applied in the rise of food industries sustainability, monitoring the processes in a more efficient way and, reducing the consumption of water and energy, turning the processes environmentally friendly. The technology Raspberry Pi has excelled in the applications, due the practicality and cost, besides being dinamic what eases its implementation in different scenarios. 
The main limitations pointed out by the authors are related to the high cost for IoT technology implementation, lack of technology for the specific application, difficulties of system implementation, lack of security of data, and necessity of specific packaging. In this sense, it brings the need for development of studies related to IoT and food industry, mainly the dairy sector which presents several limitations and presently is underexplored in Brazil.

Thereby the application of IoT in the Food Industry is suggested in terms of sensing $\mathrm{pH}$, temperature, humidity and water activity, in addition to meeting the demands of the food industry and increasing the shelf life of foods.

\section{Acknowledgments}

We would like to thank SENAI Santa Catarina Faculty that, through the internal SPROUT Notice, supported this study.

\section{References}

ABIA. (2020). Indústria de alimentos cresce 6,7\% em 2019. ABIA - Associação Brasileira Da Indústria de Alimentos. https://abia.org.br/releases/industria-dealimentos-cresce-67-em-2019

Alfian, G., Syafrudin, M., Farooq, U., Ma’arif, M. R., Syaekhoni, M. A., Fitriyani, N. L., Lee, J., \& Rhee, J. (2020). Improving efficiency of RFID-based traceability system for perishable food by utilizing IoT sensors and machine learning model. Food Control, 110 , 107016. https://doi.org/10.1016/j.foodcont.2019.107016

Alonso, R. S., Sittón-Candanedo, I., García, Ó., Prieto, J., \& Rodríguez-González, S. (2020). An intelligent Edge-IoT platform for monitoring livestock and crops in a dairy farming scenario. Ad Hoc Networks, 98, 102047. https://doi.org/10.1016/j.adhoc.2019.102047

Baralla, G., Pinna, A., Tonelli, R., Marchesi, M., \& Ibba, S. (2020). Ensuring transparency and traceability of food local products: A blockchain application to a Smart Tourism Region. Concurrency Computation, 33(1), 1-18. https://doi.org/10.1002/cpe.5857

Barros, G. S. de C. (2020). China-Brazil partnership on agriculture and food security. In P. G. and S. H. G. de M. Marcos Sawaya Jank (Ed.), China-Brazil partnership on agriculture and food security. Universidade de São Paulo. Escola Superior de Agricultura "Luiz de Queiroz." https://doi.org/10.11606/9786587391007

Bouzembrak, Y., Klüche, M., Gavai, A., \& Marvin, H. J. P. (2019). Internet of Things in food safety: Literature review and a bibliometric analysis. In Trends in Food Science and Technology (Vol. 94, pp. 54-64). Elsevier Ltd. https://doi.org/10.1016/j.tifs.2019.11.002

Duong, L. N. K., Al-Fadhli, M., Jagtap, S., Bader, F., Martindale, W., Swainson, M., \& Paoli, A. (2020). A review of robotics and autonomous systems in the food industry: From the supply chains perspective. In Trends in Food Science and Technology (Vol. 106, pp. 355-364). Elsevier Ltd. https://doi.org/10.1016/j.tifs.2020.10.028

Floarea, A. D., \& Sgârciu, V. (2016, February 21). Smart refrigerator: A next generation refrigerator connected to the IoT. Proceedings of the 8th International Conference on Electronics, Computers and Artificial Intelligence, ECAI 2016. https://doi.org/10.1109/ECAI.2016.7861170

Gupta, K., \& Rakesh, N. (2018). IoT-based solution for food adulteration. Smart Innovation, Systems and Technologies, 79, 9-18. https://doi.org/10.1007/978981-10-5828-8_2

Herrero, A. C., Martinez, F. J., Garrido, P., Sanguesa, J. A., \& Calafate, C. T. (2020). An interference-resilient IIoT solution for measuring the effectiveness of industrial processes. IECON Proceedings (Industrial Electronics Conference), 2020-Octob, 2155-2160. https://doi.org/10.1109/IECON43393.2020.9254454

Jagtap, S., Garcia-Garcia, G., \& Rahimifard, S. (2021). Optimisation of the resource efficiency of food manufacturing via the Internet of Things. Computers in Industry, 127, 103397. https://doi.org/10.1016/j.compind.2021.103397

Jain, A., Pradhan, B. K., Mahapatra, P., Ray, S. S., Chakravarty, S., \& Pal, K. (2020). Development of a low-cost food color monitoring system. Color Research and Application, 46(2), 430-445. https://doi.org/10.1002/col.22577

Kitchenham, B., \& Charters, S. (2007). Guidelines for performing Systematic Literature Reviews in Software Engineering. https://citeseerx.ist.psu.edu/viewdoc/summary?doi=10.1.1.117.471

lawal, K., \& Rafsanjani, H. nabizadeh; (2021). Trends, benefits, risks, and challenges of IoT implementation in residential and commercial buildings.

Mattas, K., \& Tsakiridou, E. (2010). Shedding fresh light on food industry's role: the recession's aftermath. In Trends in Food Science and Technology (Vol. 21, Issue 4, pp. 212-216). Elsevier. https://doi.org/10.1016/j.tifs.2009.12.005

Mededjel, M., Belalem, G., \& Neki, A. (2017). Towards a traceability system based on cloud and fog computing. Multiagent and Grid Systems, 13(1), 47-68. https://doi.org/10.3233/MGS-170261

Misiou, O., \& Koutsoumanis, K. (2021). Climate change and its implications for food safety and spoilage. In Trends in Food Science and Technology. Elsevier Ltd. https://doi.org/10.1016/j.tifs.2021.03.031

Pal, A., \& Kant, K. (2020). Smart sensing, communication, and control in perishable food supply chain. ACM Transactions on Sensor Networks, 16(1), 1-41. https://doi.org/10.1145/3360726 
Research, Society and Development, v. 11, n. 1, e0411124270, 2022

(CC BY 4.0) | ISSN 2525-3409 | DOI: http://dx.doi.org/10.33448/rsd-v11i1.24270

Paladino, Fissore, \& Neviani. (2019). A Low-Cost Monitoring System and Operating Database for Quality Control in Small Food Processing Industry. Journal of Sensor and Actuator Networks, 8(4), 52. https://doi.org/10.3390/jsan8040052

Prasanth, P., Viswan, G., \& Bennaceur, K. (2020). Development of a low-cost portable spectrophotometer for milk quality analysis. Materials Today: Proceedings. https://doi.org/10.1016/j.matpr.2020.10.327

Rahim, M. A., Rahman, M. A., Rahman, M. M., Asyhari, A. T., Bhuiyan, M. Z. A., \& Ramasamy, D. (2021). Evolution of IoT-enabled connectivity and applications in automotive industry: A review. In Vehicular Communications (Vol. 27, p. 100285). Elsevier Inc. https://doi.org/10.1016/j.vehcom.2020.100285

Sacomano, J. B. ., Gonçalves, R. F. ., Bonilla, S. H. ., Silva, M. T. da;, \& Sátyro, W. C. (2018). Indústria 4.0: conceito e fundamentos (1 ${ }^{\mathrm{a}}$ ed. São).

Safkhani, M., Rostampour, S., Bendavid, Y., \& Bagheri, N. (2020). IoT in medical \& pharmaceutical: Designing lightweight RFID security protocols for ensuring supply chain integrity. Computer Networks, 181, 107558. https://doi.org/10.1016/j.comnet.2020.107558

Sakurai, R., \& Zuchi, J. D. (2018). As revoluções industriais até a industria 4.0. Revista Interface Tecnológica, 15(2), 480-491. https://doi.org/10.31510/infa.v15i2.386

Teixeira, N., Pires, M. C., Ferreira, P., Carvalho, G. P., Santos, R., Rodrigues, F. M., Dias, J., Martins, J. C., \& Caeiro, J. J. (2020). The economic impact of a new type of ripening chamber in traditional cheese manufacturing. Sustainability (Switzerland), 12(16), 1-8. https://doi.org/10.3390/su12166682

Venkata Lakshmi, S., Janet, J., Kavitha Rani, P., Sujatha, K., Satyamoorthy, K., \& Marichamy, S. (2021). Role and applications of IoT in materials and manufacturing industries - Review. Materials Today: Proceedings, 45, 2925-2928. https://doi.org/10.1016/j.matpr.2020.11.939

Vyas, S., Shukla, V., \& Doshi, N. (2019). FMD and mastitis disease detection in cows using internet of thingh(iot). Procedia Computer Science, 160, 728733. https://doi.org/10.1016/j.procs.2019.11.019 